\title{
THE EFFECT OF SOIL GRAIN SIZE ON THE DEFORMATION PROPERTIES OF REINFORCED GEOCELL LAYERS
}

\author{
Barbara LuñáČKová*, Marek Mohyla, Miroslav Pinka
}

\author{
Technical University of Ostrava, Faculty of Civil Engineering, Department of Geotechnics and Underground \\ Engineering, 17. listopadu 2172/15, 70800 Ostrava-Poruba, Czech Republic \\ * corresponding author: barbara.lunackova@vsb.cz
}

\begin{abstract}
The effect of backfill material grading on the behaviour of geocell reinforced layers was experimentally investigated in this study. A series of loading tests were performed on a model with geocell reinforced and unreinforced layers. Five types of crushed aggregates were used as backfill materials in the experiment. The results showed that geocell reinforcement increased the deformation parameters. The rate of increase of the deformation characteristics depended on the backfill material grading.
\end{abstract}

KEYwORDS: Geocell, grading, crushed material, load plate test, deformation modulus.

\section{INTRODUCTION}

Geocells are a three-dimensional honeycomb type of geosynthetics and applied as a reinforcement to improve the behaviour of soil layers by providing lateral confinement [1-3]. The geocell system was first used by the US Army Corps of Engineers to reinforce pavements in order to improve the bearing capacity of the soil [4]. The geocell system not only increases the bearing capacity of soil but also considerably increases its stiffness and strength and reduces settlement. This is achieved by confining failure wedges that would develop in an unreinforced soil because of the lateral and outward displacement. Mandal [5] stated that lateral movement and shear failure are resisted by both the tensile hoop strength of the cell walls and the passive resistance of the full adjacent cells. Han [6] reported that base courses reinforced with geocells reduce the vertical stresses at the interface between the subgrade and base course, reduce permanent and creep deformations and increase the elastic deformation, stiffness and bearing capacity of the base course.

The most common applications of the geocell system include embankments [7, pavements [8] and erosion control [9] similar to reinforcing geogrids [10 12]. The current trend in geocell application is the use of geocells beneath foundations in order to reduce the costs associated with the construction of the foundation. The geocell system can reduce the thickness of not only the underlying layer itself but also the foundation [13].

Hegde presented a summary of previous studies, the state of the art in geocells and scope of the future directions in research in an extensive study [14. The paper discussed numerous experimental, numerical, analytical and field performance studies related to geocells. Hedge indicated several gaps in the research, such as a shortage of robust design methodologies and analytical formulations related to geocells and a lack of systematic documentation of case studies.
The common geocell description includes cell dimensions, tensile strength, seam strength, strip thickness, density and aspect ratio. Hegde [15] noted that the greater the increase in tensile strength of the material, the more confinement the geocell offers. The cell aspect ratio specifies the ratio of the geocell's aperture size to the medium grain size of the backfill. The optimum cell aspect ratio is about 15 . According to Mehrjardi [16], larger backfill particles (smaller cell aspect ratio) deteriorate the interaction between the geocell and backfill, resulting in a lower bearing capacity. However, Mehrjardi [16 also states that geocells with a cell aspect ratio of 4 have the best performance in improving the interface's shear strength. A series of direct shear tests were performed in that study to investigate the interfacial characteristics of graingrain and grain-geocell interactions. Three types of uniformly graded soils and backfill materials were classified as SP (poorly graded sand) and GP (poorly graded gravel) according to the Unified Soil Classification System, and geocells with a pocket size and height of $55 \times 55 \mathrm{~mm}$ and $50 \mathrm{~mm}$, respectively. Rajagopal [17] reported that geocell reinforcement adds apparent cohesive strength even to cohesionless soils and does not affect frictional strength.

Many researchers have observed the bearing capacity of geocell reinforced soils (e.g., [5, 6, 15, 16, 18, 20]). Mandal [5] stated that the low-settlement bearing capacity of geocell-reinforced soil did not improve much, compared to unreinforced soil, but the largesettlement bearing capacity showed a considerable improvement. He recommended using a smaller geocell opening size for low-settlement structures and a larger size for large settlement structures in order to obtain the maximum benefit from geocells.

The objective in the experiment of this study was to determine the effect of geocells on the deformation behaviour of backfill material independently of the subsoil. 


\section{Material AND Methods}

The experimental model was created for the town of Polanka (Czech Republic). Before the experiment, this location had been repeatedly used for storing crushed materials and often driven through by heavy machinery. The upper part of the subsoil $(10-15 \mathrm{~cm})$ comprised crushed aggregate that extended continuously into the lower part of the subsoil, which was classified as silty gravel (GM). A non-woven geotextile was laid onto this terrain/subsoil $\left(15 \mathrm{kN} \cdot \mathrm{m}^{-2}\right.$ tensile strength and $300 \mathrm{~g} \cdot \mathrm{m}^{-2}$ area density) followed by a $100 \mathrm{~mm}$ geocell mattress, which was covered with crushed backfill and compacted to $150 \mathrm{~mm}$ thickness using an NTC VDR 22 compacting machine $(140 \mathrm{~kg}$, $81 \mathrm{~Hz}$ frequency). The total area of the experimental model area was $2 \times 2 \mathrm{~m}$. A diagram and cross-section of the experiment is shown in Figure 1 .

The backfill materials used in this experiment were five types of crushed granular aggregates from the Hrabůvka quarry (Czech Republic). They were classified according to Czech standard ČSN 731005 [21] as GP (poorly graded gravel), S-F (sand with admixture of fine-grained soil) and G-F (gravel with admixture of fine-grained soil). The characteristics of these materials are summarized in Table 1. The particle size distribution curves of the materials are shown in Figure 2. The granularity curves were determined through a wet sieve analysis.

The geocell used in this experiment was made from high density polyethylene strips. Its basic characteristics are listed in Table 2

The deformation modulus of reinforced and unreinforced soil layers was determined through a static plate load test (PLT), which is a modulus-based compaction quality control system 22. Unfortunately, this test is restricted to a pointwise determination of deformation parameters because it is time-consuming and requires stopping the operation of the quarry. In order to overcome these limitations, a light dynamic load plate is often used in a static load plate test. Regrettably, the light dynamic load plate test proved to be unsuitable for geocell systems.

The results of the static load test showed that the subsoil in the study area can be considered incompressible. With a contact pressure of $300 \mathrm{kPa}$, the maximum settlement in this test was $1.24 \mathrm{~mm}$. The resulting modulus was $156 \mathrm{MPa}$. In terms of the experiment's boundary conditions, the subsoil could be considered qualitatively incompressible. The static load test results of the subsoil are shown in Figure 3.

The scheme of the experiment and PLT are shown in Figure 1. The overall horizontal dimensions of the model $(2 \times 2 \mathrm{~m})$ were selected according to Shadmand [13] so that the ratio between the model's width (or length) and loading plate diameter was greater than 5. The diameter of the loading plate was $300 \mathrm{~mm}$. For a proper transmission of force across the entire plate, a thin layer of sand is recommended to level the surface of the soil/aggregate layer. In order to minimize any measurement errors caused, for example, by poorly fitting the plate, each assembly was tested three times. The plate was loaded vertically in three load steps. The vertical displacements were recorded using a single gauge. The load was then incrementally reduced to zero (Fig. 3). The deformation modulus $E_{\text {def,2 }}$ from the second loading stage in the load- displacement diagram was calculated with the following equation [23]:

$$
E_{d e f, 2}=\frac{1.5 \times r}{\left(a_{1}+a_{2} \times p_{\max }\right)}
$$

where $r$ is the radius of the plate, $p_{\max }$ is the maximum pressure exerted on the plate and $a_{1}$ and $a_{2}$ are the regression constants determined by overlaying hysteresis loops with a quadratic polynomial. Figure 3 shows the application of the loaded part of the second stage of the static load test on the ground (marked in red) and its corresponding quadratic function $\left(a_{1}=1.3104, a_{2}=0.72\right)$.

Static load tests were performed on all five backfill materials with and without geocells. The ratio of cell dimensions to the loading plate was 0.63 . The effect of the loading plate size and other factors on the response from geocell reinforced backfill was investigated by Mehrjardi [16. Mehrjardi stated that the bearing capacity's tendency to vary in all conditions is incremental with an increasing loading plate size.

\section{Results AND Discussion}

The static loading test progress on the geocellreinforced and non-reinforced layers for each backfill material is shown in Figure 4. The black curves show the test's progress on the unreinforced layer, the blue curves show the layer reinforced with geocells. The dashed line shows the first load/unload stage and the solid line shows the second load/unload stage. The deformation modulus $E_{\text {def,2 }}$ was determined from these.

The static load tests were performed with a load range of $0-300 \mathrm{kPa}$. This limited load range, caused mainly by the technical equipment at the construction site, may explain why this study had a lesser benefit from the reinforcements in increasing the deformation modulus and bearing capacity of reinforced layers than other studies [5, 6, 15, 16, 18, 20].

If the differences between the maximum vertical settlement of the reinforced and unreinforced layers are compared, fractions $0 / 8$ and $0 / 32$, due to the usage of geocells, demonstrated lower settlement values than the unreinforced layer (negative difference). In fractions $4 / 8$ and $8 / 16$, the differences between the maximum settlement values of the static load plate were practically the same. Fraction 16/32 demonstrated a greater settlement in the reinforced layer with geocells than in the layer without geocells (Fig. 5). Fraction $16 / 32$ had the lowest cell aspect ratio (7.4) and highest medium grain size $(23.6 \mathrm{~mm})$ of all the backfill used. 
a)
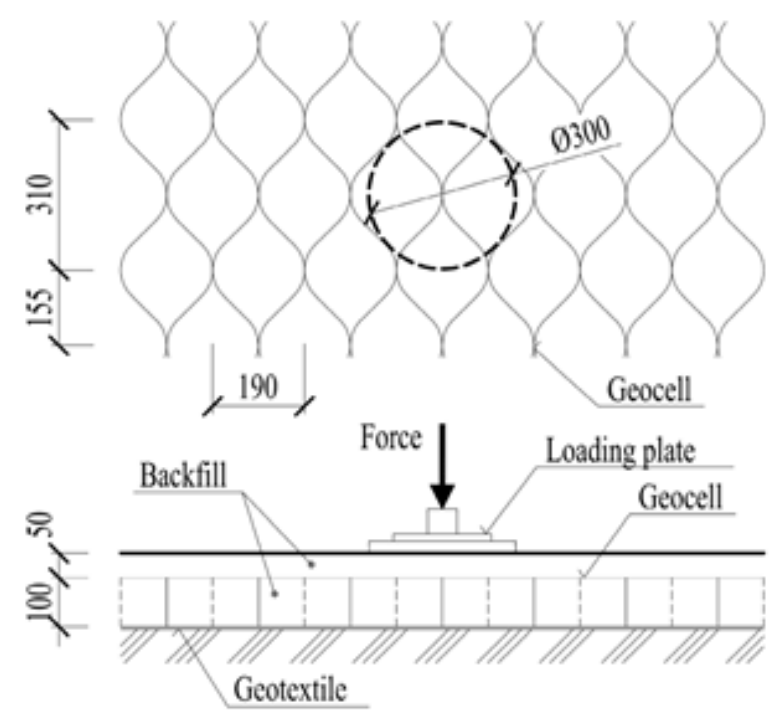

b)

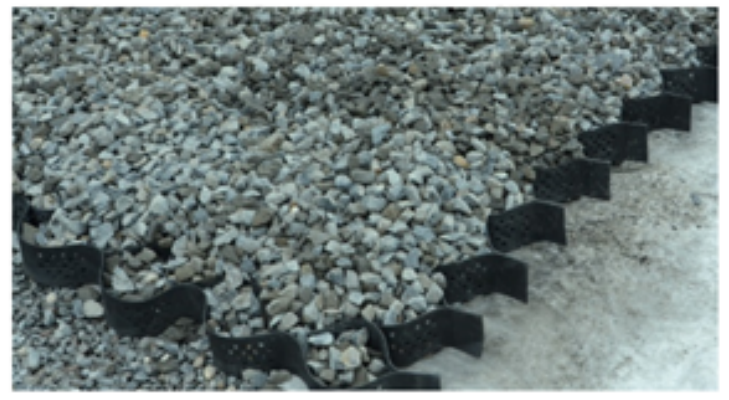

c)

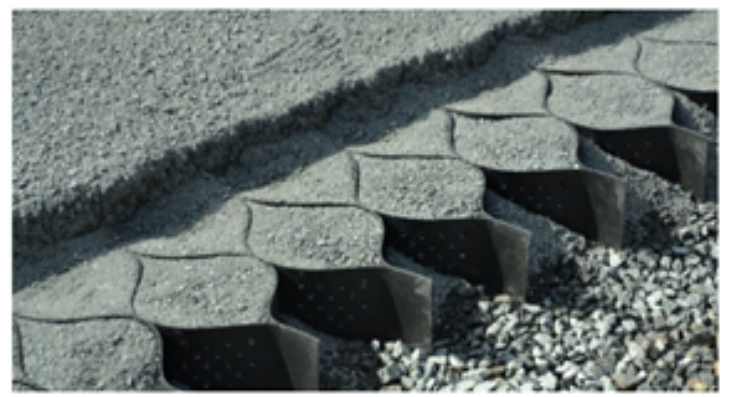

Figure 1. Large-scale model: a) geometrical scheme of the model, b) backfill - 16/32 aggregate, c) backfill 0/8 aggregate. Dimensions of the model: $2 \times 2 \mathrm{~m}$ (length $\times$ width).

\begin{tabular}{|c|c|c|c|c|c|}
\hline \multirow{2}{*}{ Characteristics } & \multicolumn{5}{|c|}{ Aggregate } \\
\hline & $4 / 8$ & $8 / 16$ & $16 / 32$ & $0 / 8$ & $0 / 32$ \\
\hline Classification (ČSN 73 1005) & GP & GP & GP & $\mathrm{S}-\mathrm{F}$ & $\mathrm{G}-\mathrm{F}$ \\
\hline Specific Gravity $\gamma_{s}\left(\mathrm{~g} \cdot \mathrm{cm}^{-3}\right)$ & 2.658 & 2.652 & 2.689 & 2.752 & 2.715 \\
\hline Moisture (\%) & 0 & 0 & 0 & 3.09 & 3.82 \\
\hline Fine Fraction $(\%)$ & 0.2 & 0.1 & 0.0 & 10.9 & 6.6 \\
\hline Sand Fraction (\%) & 1.8 & 0.5 & 0.3 & 47.1 & 18.6 \\
\hline Gravel Fraction (\%) & 98.0 & 99.4 & 99.7 & 41.0 & 74.8 \\
\hline Medium Grain Size $D_{50}(\mathrm{~mm})$ & 5.2 & 11.2 & 23.6 & 1.5 & 8.3 \\
\hline Coefficient of Uniformity $C_{U}$ & 2.2 & 1.43 & 1.51 & 35.3 & 53.1 \\
\hline Coefficient of Curvature $C_{C}$ & 1.24 & 0.95 & 0.91 & 3.31 & 3.21 \\
\hline Cell Aspect Ratio (Cell Diameter $/ D_{50}$ ) & 33.7 & 15.6 & 7.4 & 116.7 & 21.1 \\
\hline
\end{tabular}

TABLE 1. Characteristics of the backfill materials.

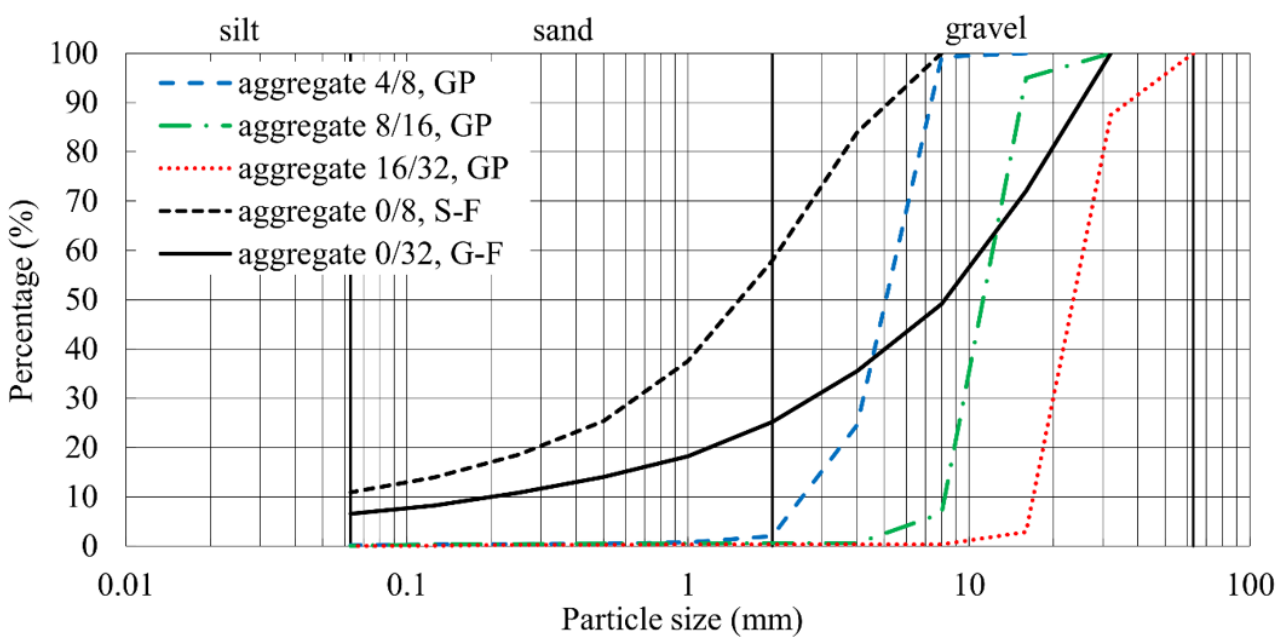

Figure 2. Particle size distribution curves. 


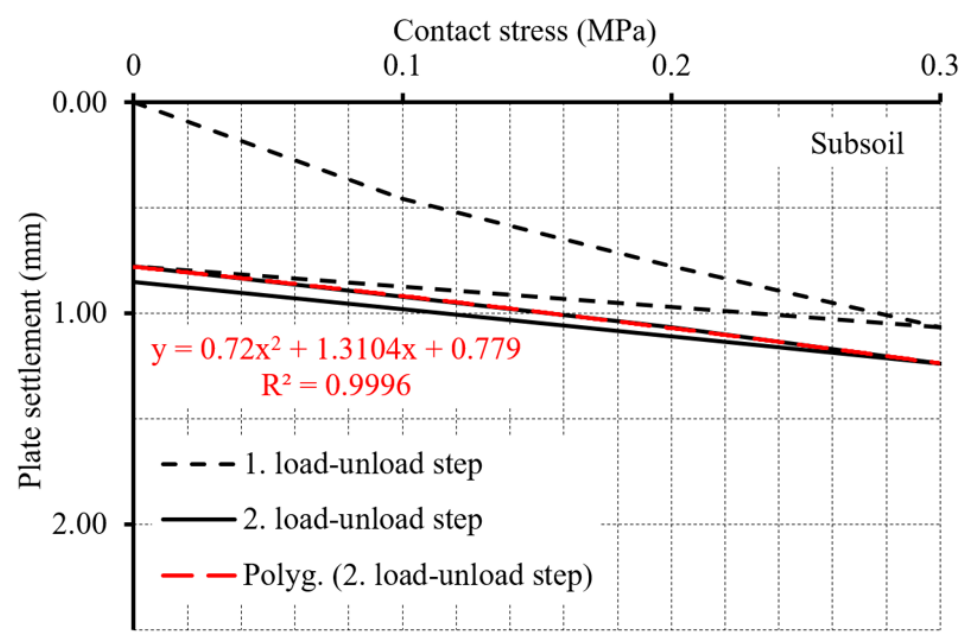

Figure 3. Polygonal regression of the second part of the hysteresis loop of the static load plate test on the subsoil.
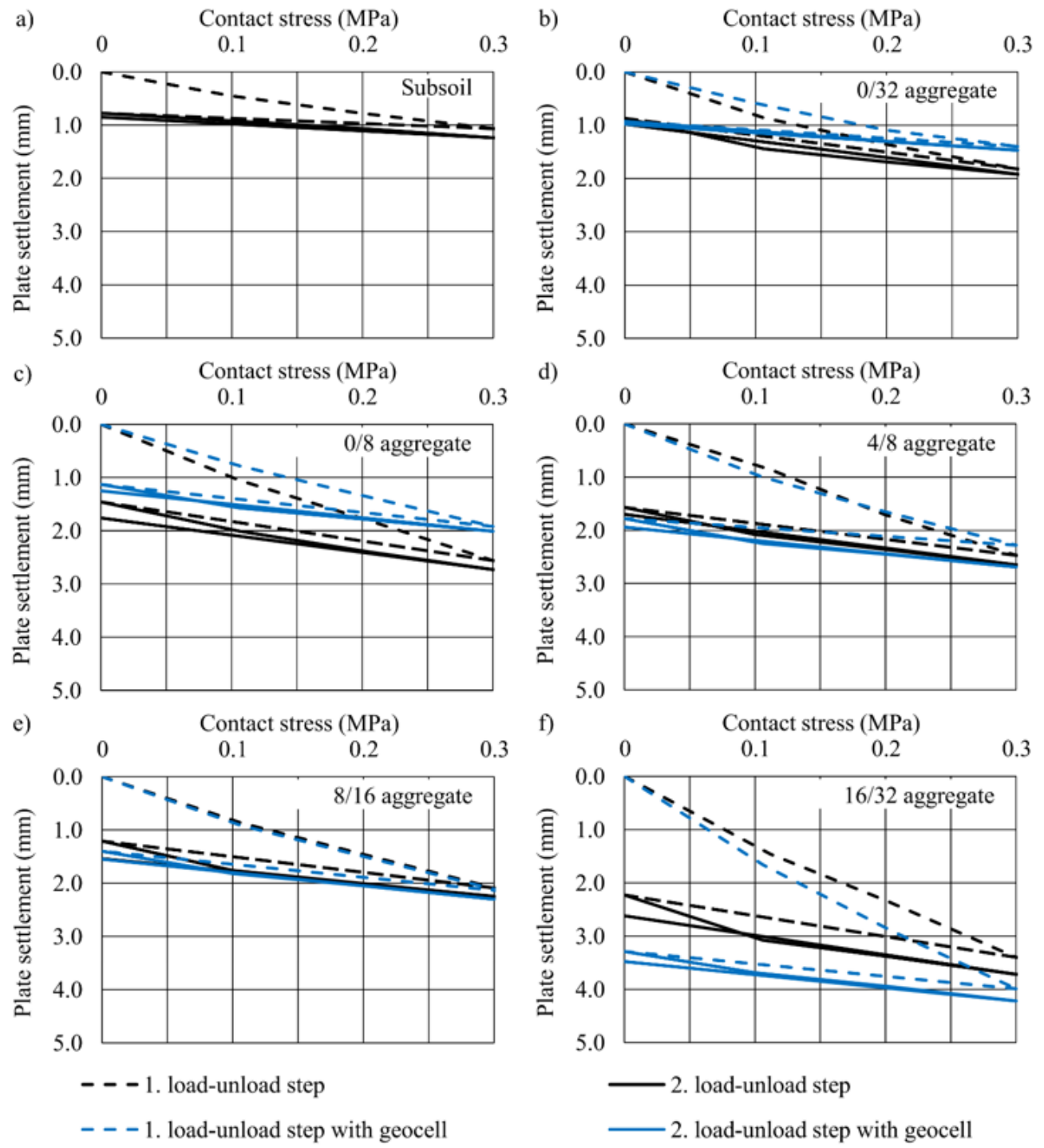

FIGURE 4. Load-displacement diagrams for static load plate tests (a) subsoil, (b) 0/32 aggregate, (c) 0/8 aggregate, (d) 4/8 aggregate, (e) 8/16 aggregate, (f) 16/32 aggregate. The black curve represents the progress of the static load test without the geocell reinforcement, the blue curve represents the progress of the test with the geocell reinforcement. 

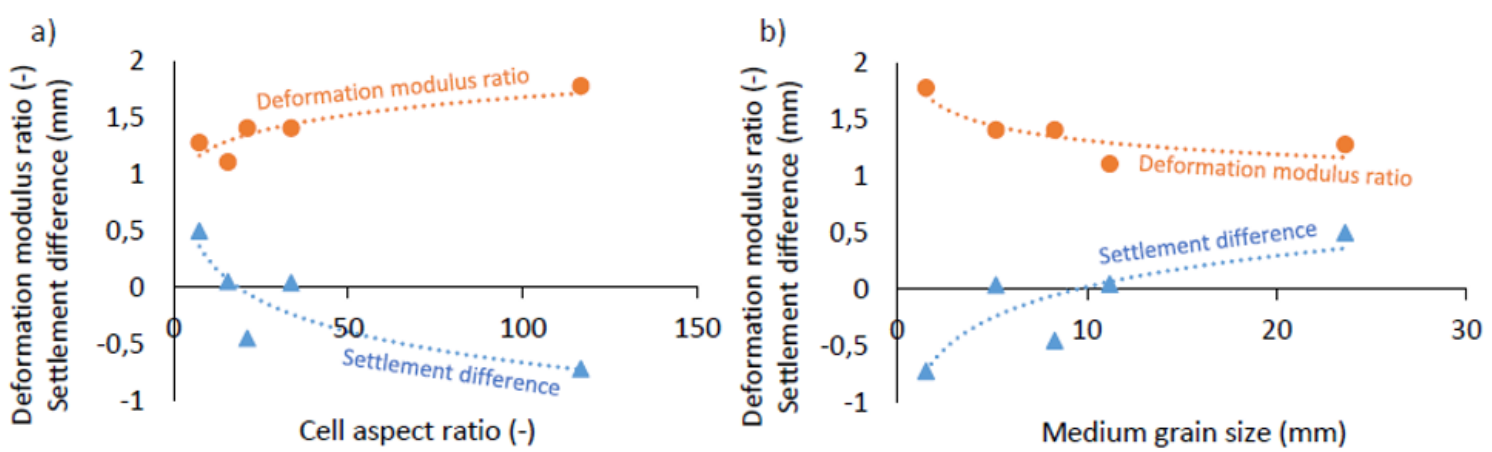

Figure 5. Deformation modulus ratio (-) and settlement difference (mm) plotted against medium grain size (mm) and cell aspect ratio (-).

\begin{tabular}{ll}
\hline Characteristics & \\
\hline Cell dimensions $(\mathrm{mm})$ & see Fig. [1 \\
Cell height $(\mathrm{mm})$ & 100 \\
Strip thickness $(\mathrm{mm})$ & 1.98 \\
Cell surface & perforated \\
Ultimate Tensile Strength $\left(\mathrm{kN} \cdot \mathrm{m}^{-2}\right)$ & 20 \\
\hline
\end{tabular}

TABLE 2. Geocell characteristics.

The objective, of course, was to achieve conditions where the vertical settlement values of the reinforced layer were less than the settlement values of the nonreinforced layer. Success depended on selecting the most suitable cell aspect ratio, i.e. the most suitable geocell mesh size and backfill grain size. Figure 5 a shows that negative differences between the reinforced and unreinforced layers were achieved with a cell aspect ratio greater than 18.5 . The change in the settlement is given by the difference between the maximum settlement values of the reinforced and non-reinforced layers from the second stage of the static load test. Negative settlement difference values mean that less settlement values were recorded for the reinforced layer than the unreinforced layer.

Using the measurement results presented in Figure 4, the deformation modulus was calculated for each backfill material. The results are summarized in Figure 6 with the type of aggregate as abscissa and deformation modulus as ordinate. Each aggregate is characterized by two values/columns. The front column characterizes the aggregate without geocells, the rear column the aggregate with geocells. It is evident that the geocell reinforcement increases the deformation parameters. The results show that the highest deformation modulus value was for $0 / 32$ aggregate reinforced with geocells, and the lowest deformation modulus value was calculated for the $0 / 8$ fraction without geocells. However, the magnitude of the deformation modulus is not as essential to this study as is the change after the use of geocells as a reinforcement system. The greatest effect of reinforcement on the deformation modulus was in the $0 / 8$ aggregate, where the deformation modulus ratio $I_{E}$ (ratio of the deformation modulus of reinforced backfill to unreinforced backfill) was 1.78 . The $0 / 8$ aggregate also had the highest cell aspect ratio of all the backfill types and the lowest medium grain size (Table 3). If the deformation modulus ratio is plotted as a function of the cell aspect ratio (Fig. 5a), it is clear that the deformation modulus ratio increased as the cell aspect ratio increased.

In the previously mentioned studies, the effect of the reinforcement is usually assessed using the bearing capacity ratio. This ratio is defined as the bearing capacity of reinforced backfill to unreinforced backfill. Most researchers generally agree that the larger the $D_{50}$ (medium grain size $=$ the diameter of the grain corresponding to $50 \%$ of the backfill), the lower the bearing capacity ratio. The same dependence was observed in this study, however, not on the bearing capacity ratio but on the deformation modulus ratio (Fig. 5b).

\section{Conclusions}

The aim of the experiment was to determine the effect of geocells on the deformation behaviour of backfill material independently of the subsoil. A series of static plate load tests were performed to observe the vertical stress-displacement responses of unreinforced layers and layers reinforced with geocells with different backfill materials. Five types of crushed aggregates were investigated in the study $(0 / 8,0 / 32,4 / 8,8 / 16$, $16 / 32$ aggregates). The subsoil was considered incompressible. The dimensions of the model were $2 \times 2 \mathrm{~m}$ and the diameter of the loading plate was $300 \mathrm{~mm}$. Only one type of geocell was used in the experiment (height of the geocell was $100 \mathrm{~mm}$ ).

From the results presented above, we can conclude that:

- the use of geocells as a reinforcement system led to an increase in layer deformation parameters in each of the $0 / 8,0 / 32,4 / 8,8 / 16,16 / 32$ fractions used,

- the greatest effect of geocell reinforcement on the deformation modulus was in the case of the aggregate with fine fractions-the $0 / 8$ aggregates, 


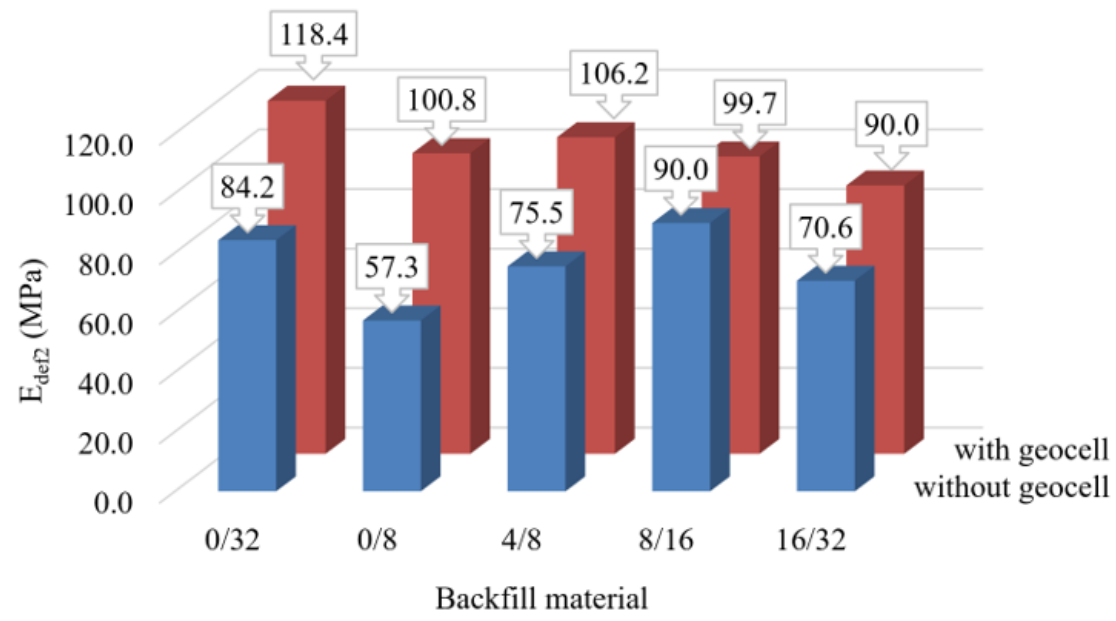

FiguRE 6. Deformation modulus from the second loading stage of the load-displacement diagram.

\begin{tabular}{lcccc}
\hline Aggregate & $I_{E}$ & Cell Aspect Ratio & $D_{50}$ & Plate Diameter $/ D_{50}$ \\
\hline $0 / 32$ & 1.41 & 21.1 & 8.3 & 36.15 \\
$0 / 8$ & 1.78 & 116.7 & 1.5 & 200 \\
$4 / 8$ & 1.41 & 33.7 & 5.2 & 57.69 \\
$8 / 16$ & 1.11 & 15.6 & 11.2 & 26 \\
$16 / 32$ & 1.28 & 7.4 & 23.6 & 12.7 \\
\hline
\end{tabular}

TABLE 3. Test results.

- the greater the value of the cell aspect ratio (the ratio of the geocell's aperture size to the medium grain size of the backfill), the greater the deformation modulus ratio (Fig. 5 a),

- the geocell filler with a cell aspect ratio greater than 18.5 had lower settlement values in the reinforced layer than the unreinforced layer (Fig. 5a) in the second load/unload stage of the static load test,

- as medium grain size of used backfill increased, the deformation modulus ratio decreased.

Further testing on materials is required to verify the presented dependencies and conclusions and to determine which medium grain size values, or more importantly, which cell aspect ratio values are the most suitable for a geocell system's performance.

\section{ACKNOWLEDGEMENTS}

This article was written under the support for long-term research projects in conceptual science and research development at VŠB - Technical University of Ostrava in 2018 provided by the Ministry of Education, Youth and Sports of the Czech Republic.

\section{LIST OF SYMBOLS}

$G P$ Poorly graded gravel

$S P$ Poorly graded sand

$G M$ Silty gravel

$G-F$ Gravel with admixture of fine-grained soil

$S-F$ Sand with admixture of fine-grained soil
$\gamma_{S} \quad$ Specific gravity $\left[\mathrm{kN} \mathrm{m}^{-3}\right]$

$D_{5}$ o Medium grain size $[\mathrm{mm}]$

$C_{U}$ Coefficient of uniformity

$C_{C}$ Coefficient of curvature

$E_{2}$ Deformation modulus [Pa]

$I_{E}$ Deformation modulus ratio

PLT Plate load test

\section{REFERENCES}

[1] S. Kolathayar, P. Suja, V. Nair, et al. Performance evaluation of seashell and sand as infill materials in HDPE and coir geocells. Innovative Infrastructure Solutions 4:7, 2019. DOI:10.1007/s41062-019-0203-6

[2] V. Hasthi, A. Hegde. Numerical analysis of machine foundation resting on the geocell reinforced soil beds. Geotechnical Engineering 49:55-62, 2018.

[3] O. Kief, Y. Schary, S. Pokharel. High modulus geocells for sustainable highway infrastructure. Indian Geotechnical Journal 45:389-400, 2014. DOI:10.1007/s40098-014-0129-z.

[4] S. L. Webster, J. E. Watkins. Investigation of construction techniques for tactical bridge approach roads across soft ground - report s-77-1. Tech. rep., Soils and Pavements Laboratory, U.S. Army Engineer Waterways Experiment Station, Vicksburg, Mississippi, 1977. https://apps.dtic.mil/dtic/tr/fulltext/u2/ a037351.pdf

[5] J. N. Mandal, P. Gupta. Stability of geocell-reinforced soil. Construction and Building Materials 8(1):55-62, 1994. DOI:10.1016/0950-0618(94)90009-4. 
[6] J. Han, J. Thakur, R. Parsons, et al. A summary of research on geocell-reinforced base courses. In International Symposium on Design and Practice of Geosynthetic-Reinforced Soil Structures - 26th Italian National Conference on Geosynthetics, pp. 331-340. Bologna, Italy, 2013. DOI:10.13140/RG.2.1.4185.7129

[7] B. Leshchinsky, H. Ling. Effects of geocell confinement on strength and deformation behavior of gravel. Journal of Geotechnical and Geoenvironmental Engineering 139:340-352, 2012. DOI:10.1061/(ASCE)GT.1943-5606.0000757.

[8] S. Pokharel, J. Han, D. Leshchinsky, R. Parsons. Experimental evaluation of geocell-reinforced bases under repeated loading. International Journal of Pavement Research and Technology 11:114-127, 2017. DOI:10.1016/j.ijprt.2017.03.007.

[9] K. J. Wu, D. N. Austin. Three-dimensional polyethylene geocells for erosion control and channel linings. In R. M. Koerner (ed.), Geosynthetics in Filtration, Drainage and Erosion Control, pp. 275-284. Elsevier, 1992. DOI:10.1016/B978-1-85166-796-3.50023-2

[10] I. Vaníček, K. I. Application and design of earth structures from the reinforced soils. Acta Polytechnica 40(2), 2000.

[11] V. Hudeček, K. Černá, L. Gembalová, J. Votoček. Completion of restoration and rehabilitation of the central tailing heap of Jan Šverma mine in Žaclér. Acta Montanistica Slovaca 21(2):129-138, 2016.

[12] V. Krivda, J. Petru, K. Zitnikova, I. Mahdalova. Road construction loaded by heavy vehicles. In 16th International Multidisciplinary Scientific Geoconference - SGEM 2016, pp. 203-208. Surveying Geology \& Mining Ecology Management (SGEM), Albena, Bulgaria, 2016.

[13] A. Shadmand, M. Ghazavi, N. Ganjian. Loadsettlement characteristics of large-scale square footing on sand reinforced with opening geocell reinforcement. Geotextiles and Geomembranes 46:319-326, 2018. DOI:10.1016/j.geotexmem.2018.01.001.

[14] A. Hegde. Geocell reinforced foundation beds-past findings, present trends and future prospects: A state-of-the-art review. Construction and Building Materials 154:658-674, 2017.

DOI:10.1016/j.conbuildmat.2017.07.230.
[15] A. Hegde, T. Sitharam. Experiment and 3D-numerical studies on soft clay bed reinforced with different types of cellular confinement systems. Transportation Geotechnics 10:73-84, 2017. DOI:10.1016/j.trgeo.2017.01.001

[16] G. T. Mehrjardi, R. Behrad, S. N. Moghaddas Tafreshi. Scale effect on the behavior of geocell-reinforced soil. Geotextiles and Geomembranes 47:154-163, 2019. DOI:10.1016/j.geotexmem.2018.12.003

[17] K. Rajagopal, N. R. Krishnaswamy, G. M. Latha. Behaviour of sand confined with single and multiple geocells. Geotextiles and Geomembranes 17(3):171-184, 1999. DOI:10.1016/S0266-1144(98)00034-X

[18] S. Pokharel, J. Han, D. Leshchinsky, et al. Investigation of factors influencing behavior of single geocell-reinforced bases under static loading. Geotextiles and Geomembranes 28:570-578, 2010. DOI:10.1016/j.geotexmem.2010.06.002

[19] S. N. Moghaddas Tafreshi, A. Dawson. Laboratory model tests for a strip footing supported on geocell reinforced sand bed. In Ground Improvement and Geosynthetics, pp. 353-360. 2010. DOI:10.1061/41108(381)46

[20] N. K. Kumawat, S. K. Tiwari. Bearing capacity of square footing on geocell reinforced fly ash beds. Materials Today: Proceedings 4(9):10570-10580, 2017. DOI:10.1016/j.matpr.2017.06.422.

[21] ČSN P 731005 - Inženýrskogeologický průzkum (Ground investigation). Standard, Úrad pro technickou normalizaci, metrologii a státní zkušebnictví, Praha, 2016.

[22] Y.-J. Choi, D. Ahn, T. Nguyen, J. Ahn. Assessment of field compaction of aggregate base materials for permeable pavements based on plate load tests. Sustainability 10:1-13, 2018. DOI:10.3390/su10103817.

[23] D. Adam, F. Kopf, I. Paulmichl. Computational validation of static and dynamic plate load testing. Acta Geotechnica 4:35-55, 2009. DOI:10.1007/s11440-008-0081-0. 